\title{
Effect of Planting Season in the Crop Production in Indian States
}

\author{
Shivali Amit Wagle a , Harikrishnan R ${ }^{\mathrm{a}, *}$ \\ ${ }^{a}$ Electronics and Telecommunication Engineering Department, Symbiosis Institute of Technology, Symbiosis International University, Lavale, \\ Mulshi, Pune, Maharashtra 412115, India \\ Corresponding author: ${ }^{*}$ rhareish@gmail.com
}

\begin{abstract}
As the population grows and meets the demand for food, it is necessary to increase the production rate. This can be done by choosing the proper season for the crop and employing the cultivation land. The data analysis study is conducted on 124 crop varieties in the 33 Indian states in different weather conditions. The data analysis used a two-factor experimental design. The data analysis helps the farmer select the crop in the region and weather conditions that can have more productivity results. The study shows that the Kharif and Rabi season is the most favorable season for agriculture. Other than these seasons, agricultural activities are also done in summer, winter, autumn, and the whole year. The yield from the crops based on the seasonal weather information is a challenge in the agricultural sector. Amongst the variety of fruits, vegetables, seeds, and nuts, the majorly grown are pulses in all the states, rice has the largest producers. Data analysis is an important concept to understand the data wisely. This study helps the smallholder farmer in decision making to increase crop productivity due to climate risk and trends. There is a vulnerability in agricultural production due to a change in weather conditions. This can arise from food security issues if proper knowledge of crop selection is not done.
\end{abstract}

Keywords - Crop production; weather; plantation area.

Manuscript received 12 Dec. 2020; revised 2 Apr. 2021; accepted 6 May 2021. Date of publication 31 Dec. 2021. IJASEIT is licensed under a Creative Commons Attribution-Share Alike 4.0 International License.

\section{INTRODUCTION}

Agriculture is India's backbone, as it is practiced for food production in almost all of the country's states. Data analysis is beneficial because it enables to understand different aspects of the crop production dataset, such as cultivation position, season, and weather conditions. As the world's population continues to grow, so does the demand for food. Different strategies should be followed by the smallholder farmer for decision-making in the crop selection for weather conditions and terrain conditions for better produce [1]. Farmers can be informed about the data analysis through media such as radio, television, and social gatherings organised by village officials [2]. Autumn, kharif, rabi, summer, winter, and whole-year crops are all grown in India's 33 states. For high productivity, a crop needs specific weather and terrain conditions [3], [4]. If a farmer has access to knowledge about this over time, it may assist him in determining which crop to cultivate. Climate has a major effect on plant growth in terms of plant form, species, and cropping pattern in geographic distribution [5]-[7]. The best weather condition for apple is cold in winter or the moderate summer temperature with a medium to high humidity level. The delicious taste and low calorie content makes it more in demand [8]. India is the world's largest mango producer, with an annual income of 1.4 million tons from export. Mango is a tropical fruit that thrives in frost-free climates with cold, dry winters and warm, humid summers [9].

Pulses are the most protein-dense and cost-effective source of protein in the meal. Pulses contain the same amount of calories as cereals but the protein content varies [10]. Tur dal is the most used protein source in all households. It requires the most and warm weather with low temperatures [11]. In a hot and humid climate, rice crops need long periods of sunlight and a certain amount of water. Wheat, too, requires a lot of sunlight and a low humidity level during the grain filling stage. Horticulture crops account for approximately $30 \%$ of the agricultural GDP. The cultivation land of 11.6 million hectares area gives a yearly production of 91 million tons [12].

Horticultural crops boost the economic situation of rural farmers [13]. Crops are profitable when they are adapted to the regions in which they are produced [14]. India produces $10 \%$ of the world's fruit and $13 \%$ of the world's vegetable production. India is also the world's second-largest producer of fruits and vegetables. In Indian states, mango, cashew nut, banana, sapota, and lemon are grown on a larger scale. Vegetables such as onion, potato, peas of different varieties, cabbage, cauliflower, brinjal, and tomato are also widely grown here. Tomatoes are a popular crop around the world 
because they add nutritious value to a diet by providing an excellent source of vitamin $\mathrm{C}$ and antioxidants. Tomatoes are a warm-season crop that grows best in subtropical and mildly cold climates. Rainfall, temperature, and humidity influence the yield and quantity of tomatoes grown for commercial purposes [15]. The paper addresses the data analysis performed on the Kaggle dataset for crop production [16], which includes state-by-state and area-by-area crop production under various weather conditions. Section II discusses the methods for data analysis, accompanied by section III results and discussion, and section IV conclusion.

\section{MATERIAL AND Method}

\section{A. Dataset of crop production}

The dataset of crop production in different weather conditions of Indian states is considered here [16]. The dataset also has the information of the crop cultivation district wise. 124 crop types are produced in various regions of the country.
The crop variety consists of fruits, vegetables, pulses and cereal, seeds and nuts, and miscellaneous. The crop cultivation depends majorly on the season in which the harvesting is done. Certain crops have favorable conditions of larger yield in particular weather and particular terrain. Some crops require cold weather, whereas some require moderate to hot weather, and some crops can be grown throughout the year.

The block diagram of the workflow is shown in Fig. 1. Crop production data is divided into five categories: fruits, vegetables, pulses and cereals, seeds and nuts, and miscellaneous. Crops that are grown in accordance with the best season conditions are graded. The crops developed in the autumn, kharif, rabi, summer, winter, and the entire year are listed. Some crops are cultivated all year long. The database on crop production and the area in which cultivation is done is subjected to statistical analysis. The crop's maximum yield and gross crop production are also determined seasonally. The crop production in each state is assessed.

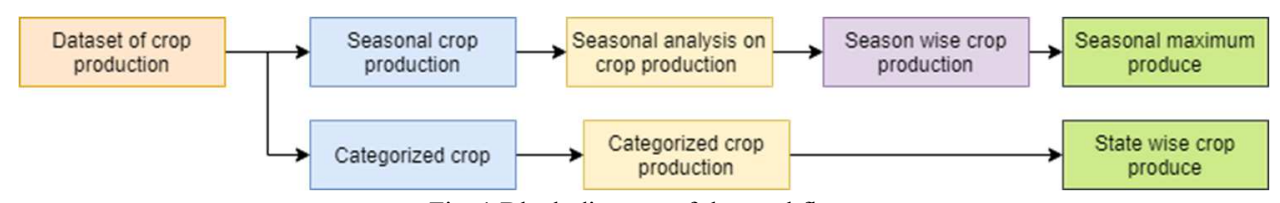

Fig. 1 Block diagram of the workflow.

\section{B. Seasonal Data Analysis}

The analysis will help in understanding the crop to choose by the farmer in his terrain for maximum cultivation rate. The agriculture activities of autumn, kharif, rabi, summer, and whole year helps in understanding the crop productivity in that season. The Autumn season usually lasts between September and October. Autumn is the season after the rainy season and before the pre-winter season. Kharif season in India is from June to October. Kharif crops are sown at the beginning of the first rains and harvested at the end of monsoon season October-November. The crops that are sown in the winter season are called Rabi crops. Summer crops are grown between March and June. Certain crops can be grown throughout the year. Table I shows the crops that are widely grown in different seasons in different regions of the country.

TABLE I

CROPS THAT ARE GROWN IN DIFFERENT SEASONS

\begin{tabular}{|c|c|}
\hline Season & Crop Produced \\
\hline Autumn & $\begin{array}{l}\text { Arhar/Tur, Banana, Cotton(lint), Dry chilli, Dry ginger, Groundnut, Jowar, Jute, Maize, Moong (Green Gram), Onion, Paddy, } \\
\text { Peas \& beans (Pulses), Potato, Ragi, Rice, Sannhamp, Sesamum, Small millets, Soyabean, Sugarcane, Sweet potato, Tapioca, } \\
\text { Turmeric, Urad }\end{array}$ \\
\hline Karif & $\begin{array}{l}\text { Arecanut, Arhar/Tur, Bajra, Banana, Barley, Bean, Black pepper, Blackgram, Brinjal, Cabbage, Cardamom, Cashewnut, Castor } \\
\text { seed, Coconut, Colocosia, Cond-spcs other, Coriander, Cotton(lint), Cowpea(Lobia), Dry chillies, Dry ginger, Garlic, Ginger, } \\
\text { Gram, Grapes, Groundnut, Guar seed, Horse-gram, Jobster, Jowar, Jute,Jute \& mesta, Kapas, Khesari, Korra, Lemon, Linseed, } \\
\text { Maize, Mango, Masoor, Mesta, Moong(Green Gram), Moth, Niger seed, Oilseeds total, Onion, Orange, Other Cereals \& Millets, } \\
\text { Other Kharif pulses, other misc. pulses, other oilseeds, Paddy, Papaya, Peas \& beans (Pulses), Perilla, Pome Granet, Potato, } \\
\text { Pulses total, Ragi, Rajmash Kholar, Rapeseed \&Mustard, Rice, Ricebean (nagadal), Safflower, Samai, Sannhamp, Sapota, } \\
\text { Sesamum, Small millets, Soyabean, Sugarcane, Sunflower, Sweet potato, Tapioca, Tea, Tobacco, Tomato, Total foodgrain, } \\
\text { Turmeric, Urad, Varagu, Wheat }\end{array}$ \\
\hline Rabi & $\begin{array}{l}\text { Arecanut, Arhar/Tur, Bajra, Banana, Barley, Black pepper, Blackgram, Brinjal, Cabbage, Cashewnut, Castor seed, Cond-spcs } \\
\text { other, Coriander, Cotton(lint), Cowpea(Lobia), Dry chillies,Dry ginger, Garlic, Ginger, Gram, Groundnut, Horse-gram, Jowar, } \\
\text { Jute, Khesari, Korra, Lentil, Linseed, Maize, Masoor, Mesta, Moong(Green Gram), Moth, Niger seed, Oilseeds total, Onion, } \\
\text { Other Rabi pulses, Other Cereals \& Millets, Other Kharif pulses, other misc. pulses, other oilseeds, Paddy, Papaya, Peas \& beans } \\
\text { (Pulses), Pineapple, Potato, Pulses total, Ragi, Rajmash Kholar, Rapeseed \&Mustard, Rice, Safflower, Samai, Sannhamp, } \\
\text { Sesamum, Small millets, Soyabean, Sugarcane, Sunflower, Sweet potato, Tapioca, Tobacco, Tomato, Total foodgrain, } \\
\text { Turmeric, Urad, Varagu, Wheat }\end{array}$ \\
\hline Summer & $\begin{array}{l}\text { Arhar/Tur, Bajra, Banana, Brinjal, Cotton(lint), Cowpea (Lobia), Dry chillies, Dry ginger, Groundnut, Horse-gram, Jowar, Jute, } \\
\text { Maize, Moong(Green Gram), Onion, Other Rabi pulses, Paddy, Peas \& beans (Pulses), Potato, Pulses total, Ragi, Rice, } \\
\text { Sesamum, Small millets, Sugarcane, Sunflower, Tobacco, Total foodgrain, Turmeric, Urad, Wheat }\end{array}$ \\
\hline $\begin{array}{l}\text { Whole } \\
\text { Year }\end{array}$ & $\begin{array}{l}\text { Apple, Arcanut (Processed), Arecanut, Arhar/Tur, Ash Gourd, Atcanut (Raw), Bajra, Banana, Barley, Beans \& } \\
\text { Mutter(Vegetable), Beet Root, Ber, Bhindi, Bitter Gourd, Black pepper, Blackgram, Bottle Gourd, Brinjal, Cabbage, Cardamom, } \\
\text { Carrot, Cashewnut, Cashewnut Processed, Cashewnut Raw, Castor seed, Cauliflower, Citrus Fruit, Coconut, Coffee, Coriander, } \\
\text { Cotton(lint), Cowpea(Lobia), Cucumber, Drum Stick, Dry chillies, Dry ginger, Garlic, Ginger, Gram, Grapes, Groundnut, Guar }\end{array}$ \\
\hline
\end{tabular}


seed, Horse-gram, Jack Fruit, Jowar, Jute \& mesta, Kapas, Khesari, Lab-Lab, Linseed, Litchi, Maize, Mango, Masoor, Mesta, Moong(Green Gram), Moth, Niger seed, Oilseeds total, Onion, Orange, Other Citrus Fruit, Other Dry Fruit, other fibres, Other Fresh Fruits, other oilseeds, Other Vegetables, Papaya, Peach, Pear, Peas (vegetable), Peas \& beans (Pulses), Pineapple, Plums, Pome Fruit, Pome Granet, Potato, Pulses total, Pump Kin, Ragi, Rapeseed \&Mustard, Redish, Ribed Guard, Rice, Rubber, Safflower, Sannhamp, Sesamum, Small millets, Snak Guard, Soyabean, Sugarcane, Sunflower, Sweet potato, Tapioca, Tea, Tobacco, Tomato, Total foodgrain, Turmeric, Turnip, Urad, Water Melon, Wheat, Yam

Winter Arhar/Tur, Banana, Coriander, Cotton(lint), Dry chillies, Dry ginger, Gram, Groundnut, Horse-gram, Maize, Moong(Green Gram), Niger seed, Onion, Paddy, Peas \& beans (Pulses), Potato, Ragi, Rapeseed \&Mustard, Rice, Sannhamp, Sesamum, Soyabean, Sugarcane, Sunflower, Sweet potato, Turmeric, Urad, Wheat

\section{Categorization of Crop}

The crops are further categorized for a better understanding of the data. 124 crop varieties are divided into fruits, vegetables, pulses and cereal, seeds, and nuts, and miscellaneous, as shown in Fig. 2. The categorization is done to fit all the data in a smaller frame and understand and analyze the data. Major of the crops fall under vegetables, pulses and cereal, and seeds and nuts.

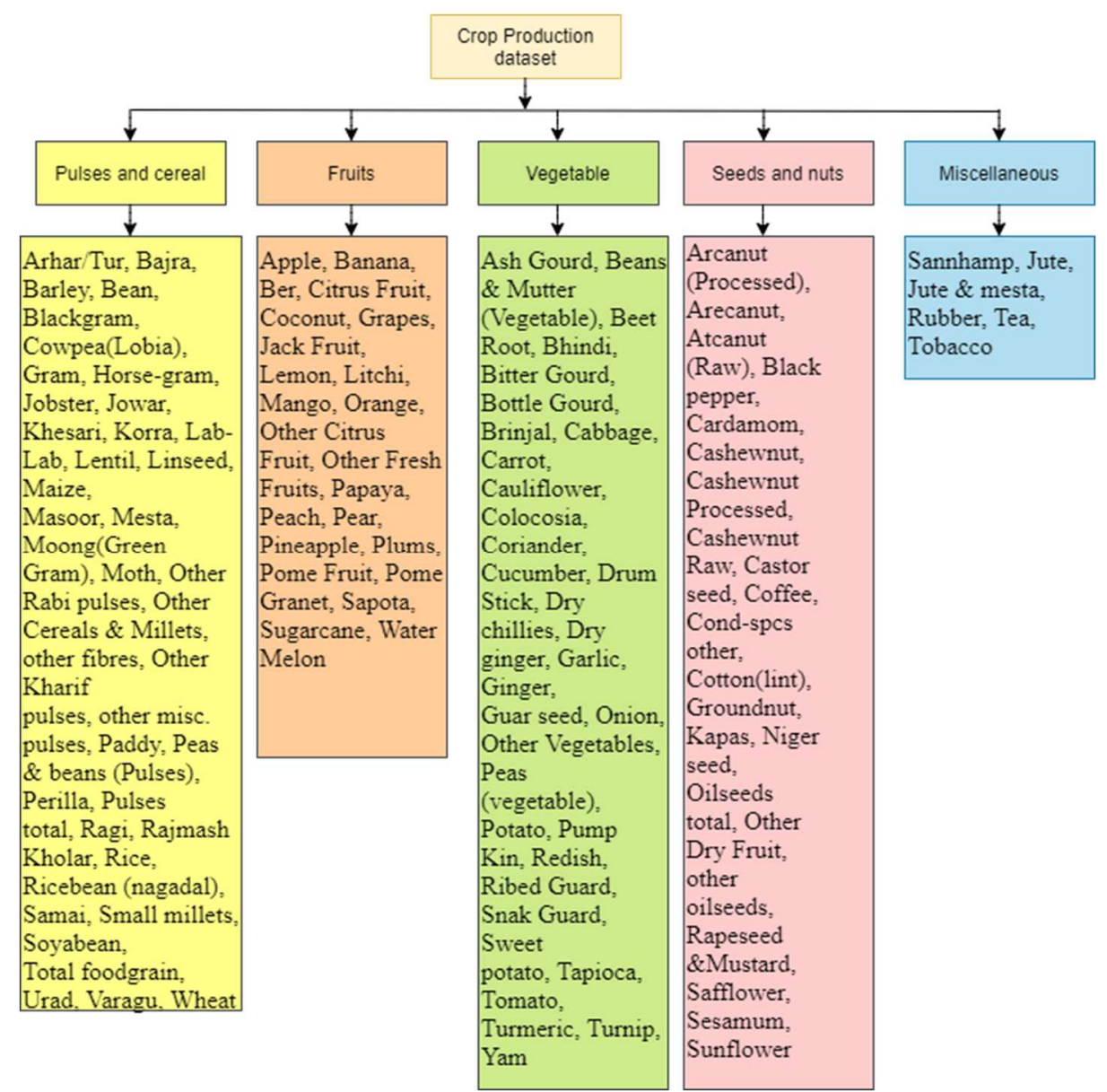

Fig. 2 Categorized crop as pulses and cereal, fruits, vegetables, seeds and nuts and miscellaneous.

\section{RESULTS AND DISCUSSION}

The data analysis on crop production is done on the seasons of Autumn, Kharif, Rabi, Summer, and the whole year in terms of area and production. To assess the influence of climate indexes, a state-by-state impact analysis is performed by [17] for kharif and rabi crops. The most worrying physiological response to climate change is a shorter growing season, which results in a major reduction in fruit and vegetable production. Crop-based adaptation strategies are needed, taking into account the crop's existence, sensitivity level, and geographical location [18]. The food grain yield per hectare land is used as a dependent variable that is regressed with different socio-economic and climatic variables to predict crop production in various climate change scenarios
[19]. Temperature and precipitation variations have an effect on crop production all over the world. As a result, these alternative grains hold promise for reducing fluctuations in Indian grain output in response to climate shocks. However, preventing grain production shortfalls as a result of increased alternative grains would necessitate yield improvements that do not jeopardise their superior climate resilience [20].

Over a 58-year duration (1961-2017), [4] investigates the effect of climatic variables such as rainfall, maximum, and minimum temperatures on crop yields for seven major crops: rice, wheat, pulses, rapeseeds, and mustard, cotton, sugarcane, and groundnut. The empirical results show that rainfall, maximum and minimum temperatures have a significant effect on major crop yields, but the extent of the impact varies 
across the crops studied. Except for pulses, increased rainfall has a negative impact on food crops, but it has a positive impact on non-food crops during the study period.

A statistically downscaled MPI-ESM-MR model in NEXGDDP simulated daily precipitation, minimum and maximum temperature, and indicates a substantial reduction in the output of three major crops: sugarcane, cotton, and rice [21]. Rice and wheat threats have risen in the last decade, with wheat being two times more dangerous than rice. The decreasing number of cultivators is found to be the primary driver of increasing crop risk; in particular, the wheat risk is related to rising minimum temperatures during the crop growing season [22]. The yield potential of sweet corn inbred lines and to estimate genetic parameters for producing varieties suitable for organic cropping systems was studied by [23].

Descriptive analysis of the land area and the production from it through yield is shown in Table II and Table III. The Kharif season is the most favorable season in which major agricultural tasks are done for the larger yield, and the autumn season is the span where the agricultural activities are low. The area of 95951 hectares is used for cultivation, giving 94283 tons of crop production in the Kharif season. The Rabi season has 66987 hectares of land area for cultivation producing 66160 tons of crops. Summer crops produce 14811 tons in 14841 hectares of land. The winter and autumn season have lower production abilities as compared to other seasons.

TABLE II

SEASON ANALYSIS AREA WiSE

\begin{tabular}{lcccccc}
\hline Parameter & \multicolumn{7}{c}{ Area } \\
& Autumn & Kharif & Rabi & Summer & Whole Year & Winter \\
\hline Valid & 4949 & 95951 & 66987 & 14841 & 57305 & 6058 \\
Missing & 0 & 0 & 0 & 0 & 0 & 0 \\
Mean & 9713 & 14641 & 14152 & 5120 & 4490 & 36249 \\
Std. Deviation & 18437 & 44383 & 69443 & 21360 & 35355 & 67441 \\
Minimum & 1.000 & 0.100 & 0.580 & 1.000 & 0.040 & 1.000 \\
Maximum & 212760 & $1.02 \mathrm{e}+6$ & $8.58 \mathrm{e}+6$ & 687000 & $4.31 \mathrm{e}+6$ & 513019 \\
\hline
\end{tabular}

TABLE III

SEASONAL ANALYSIS ON PRODUCTION

\begin{tabular}{lcccccc}
\hline \multicolumn{1}{c}{ Parameter } & \multicolumn{7}{c}{ Production } & & \\
& Autumn & Kharif & Rabi & Summer & Whole Year & Winter \\
\hline Valid & 4930 & 94283 & 66160 & 14811 & 56127 & 6050 \\
Missing & 19 & 1668 & 827 & 30 & 1178 & 8 \\
Mean & 13066 & 42743 & 31011 & 11522 & $2.40 \mathrm{e}+6$ & 71826 \\
Std. Deviation & 28295 & 375516 & 127883 & 48316 & $3.54 \mathrm{e}+7$ & 159872 \\
Minimum & 0.100 & 0.000 & 0.000 & 0.000 & 0.000 & 0.100 \\
Maximum & 542692 & $1.78 \mathrm{e}+7$ & $7.56 \mathrm{e}+6$ & 882289 & $1.25 \mathrm{e}+9$ & $1.84 \mathrm{e}+6$ \\
\hline
\end{tabular}

Fig. 3 shows the season-wise production in the country. The Kharif and Rabi are the most favorable seasons having the largest productivity followed by summer and whole year season. The crops give different productivity seasonally. Table IV shows the crops giving maximum production from the crops in a different season. India is having the largest production of rice as compared to other crop varieties. The state-wise agricultural produce is shown in Fig. 4. Uttar Pradesh is showing the largest produce followed by Madhya
Pradesh, Karnataka, Bihar, Assam, Odisha, Tamil Nadu, Maharashtra, Rajasthan, Chhattisgarh amongst the top ten agriculture produce states. Fig. 5 shows the state-wise crop produce into categories of pulses and cereals, fruits, vegetables, seeds and nuts, and miscellaneous of 124 crops for 33 states. The pie chart shows the percentage-wise crop produce of the state. Overall, it is seen that pulses and cereals are grown majorly in all states.

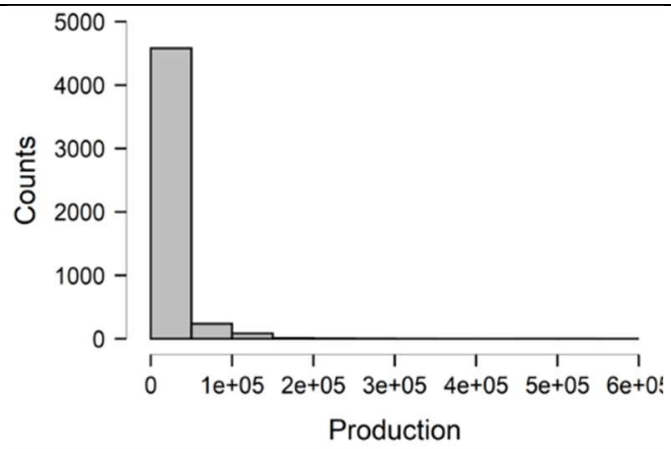

(a) Autumn season production

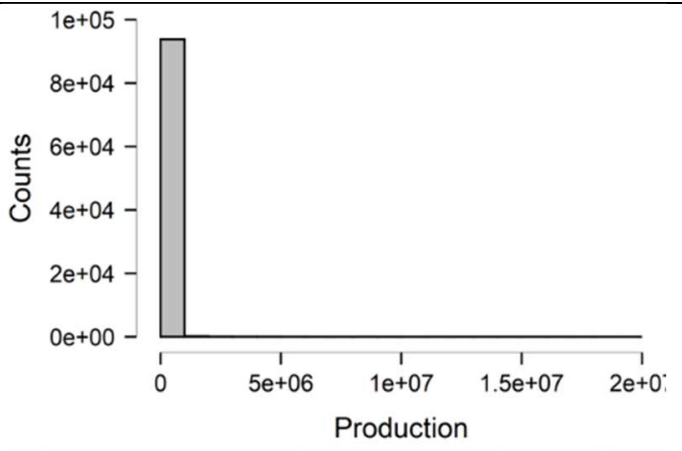

(b) Kharif season production 


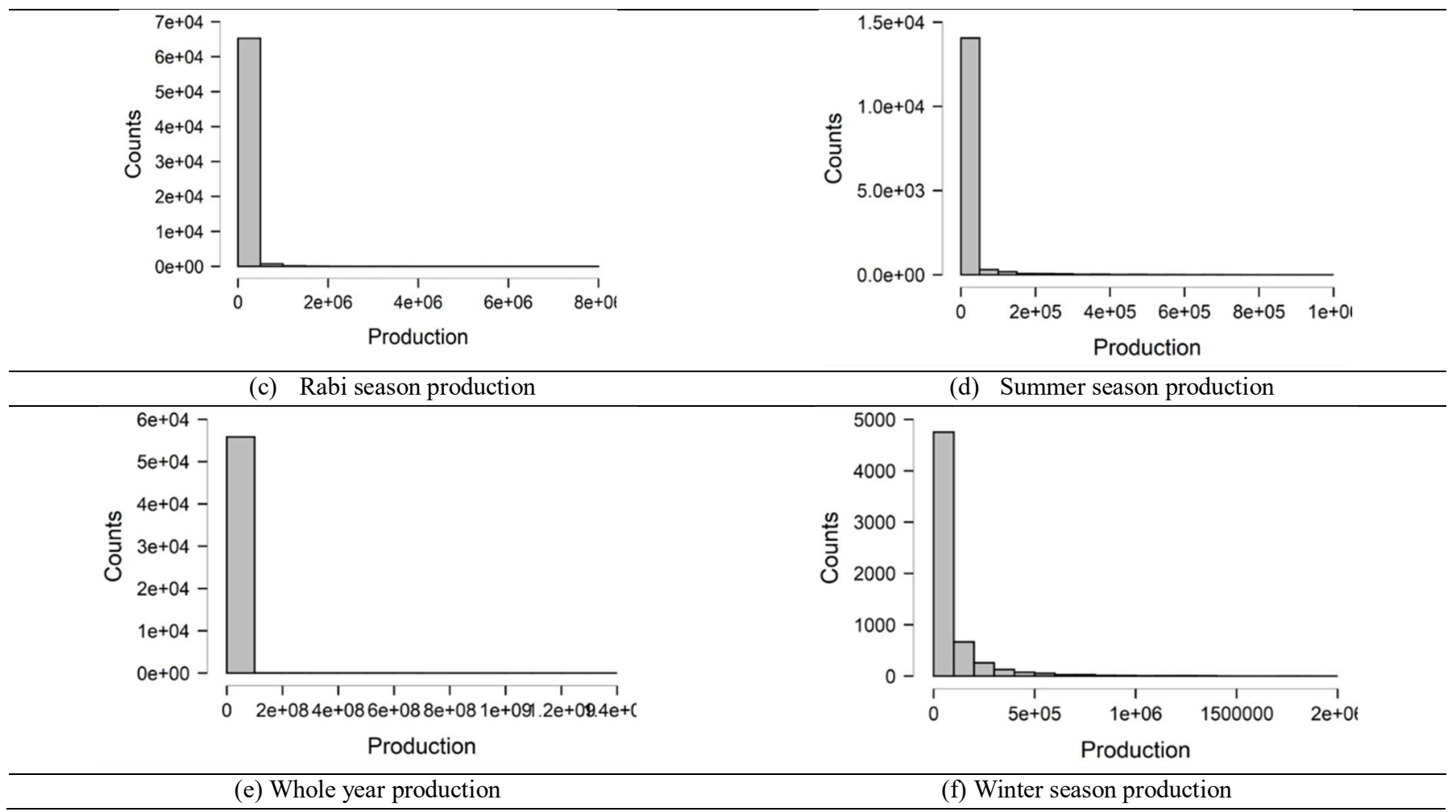

Fig. 3 Season wise production

TABLE IV

Crops Giving MAXIMUM Production FROM THE CROPS IN DIFFERENT SEASON

\begin{tabular}{ll}
\hline Season & Crops maximum production \\
\hline Autumn & Rice \\
\hline Kharif & $\begin{array}{l}\text { Maize, Rice, Arhar/Tur, Sesamum, Urad, Moong(Green Gram), Groundnut, Jowar, Bajra, Small millets, Cotton(lint), Other Kharif } \\
\text { pulses, Soyabean, Castor seed, Sunflower, Ragi, Horse-gram, Niger seed, Mesta, Dry ginger, Jute, Dry chillies, Sugarcane }\end{array}$ \\
\hline Rabi & $\begin{array}{l}\text { Wheat, Gram, Rapeseed \&Mustard, Linseed, Masoor, Barley, Peas \& beans (Pulses), Other Rabi pulses, Maize, Moong (Green } \\
\text { Gram), Urad, Sunflower, Potato, Jowar, Onion, Khesari, Safflower, Horse-gram }\end{array}$ \\
\hline Summer & $\begin{array}{l}\text { Rice, Maize, Moong(Green Gram), Groundnut, Urad, } \\
\text { Sunflower }\end{array}$ \\
\hline Whole year & Sugarcane, Potato, Dry chillies, Onion, Turmeric, Sweet potato, Coriander, Banana, Garlic, Tobacco, Coconut, Dry ginger, \\
& Sannhamp, Arecanut, Tapioca, Cashewnut \\
\hline Winter & Rice \\
\hline
\end{tabular}

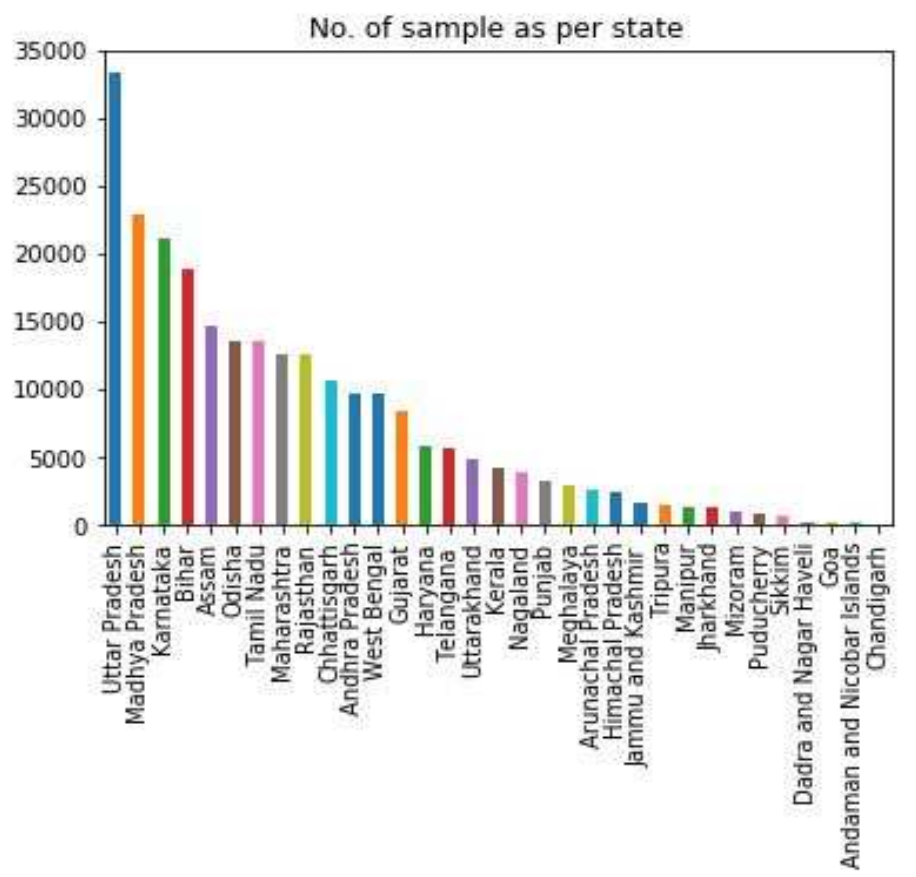

Fig. 4 State wise agriculture produce. 

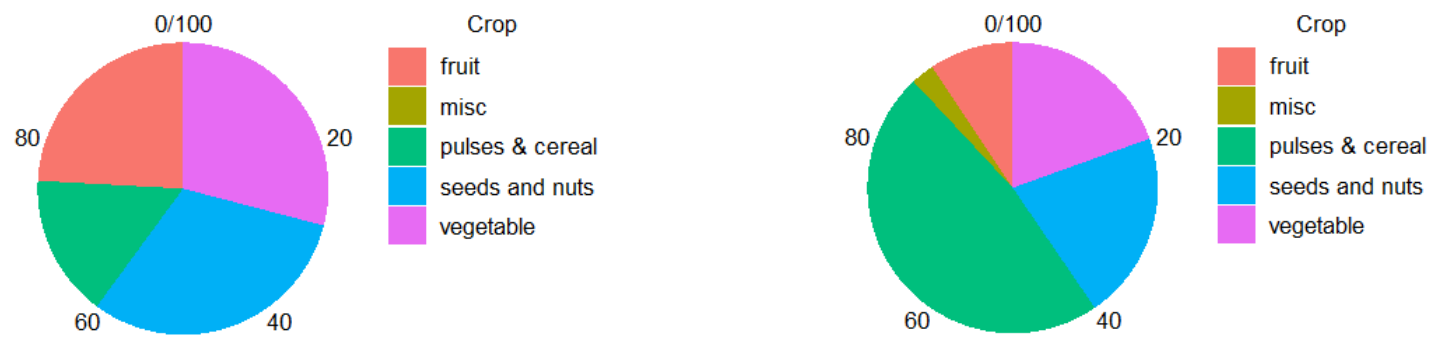

Andaman and Nicobar Islands
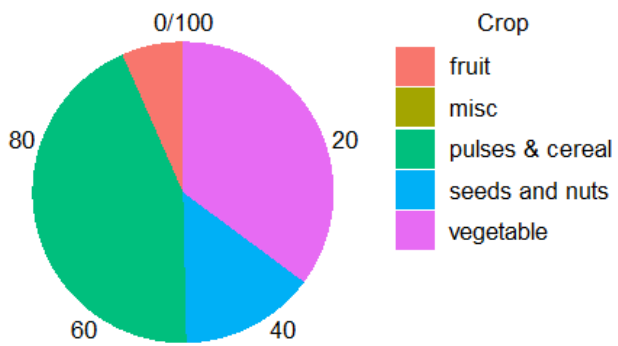

Arunachal Pradesh

Crop

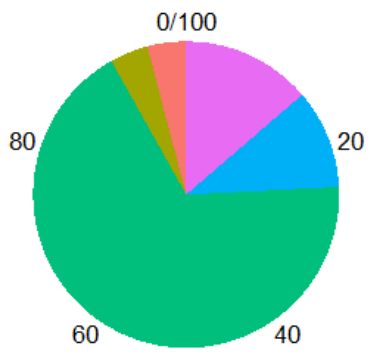

fruit

misc

pulses \& cereal

seeds and nuts

vegetable

Bihar

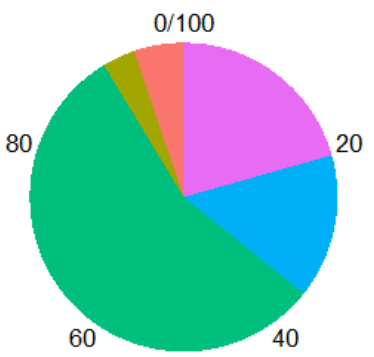

Crop

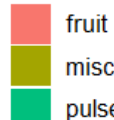

misc

pulses \& cereal

seeds and nuts

vegetable

Chhattisgarh

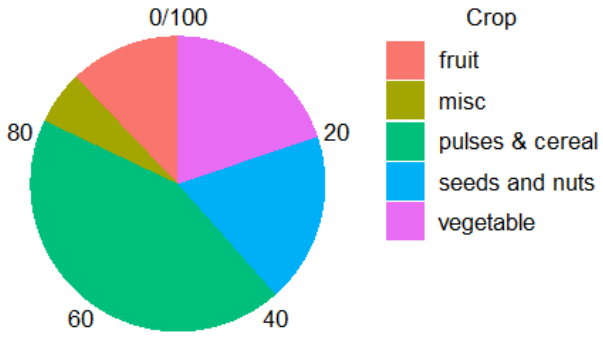

Assam

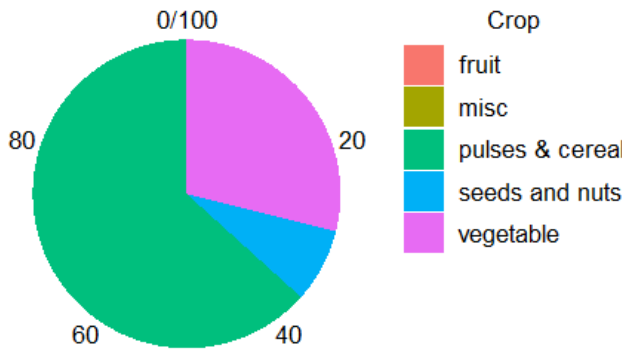

Chandigarh

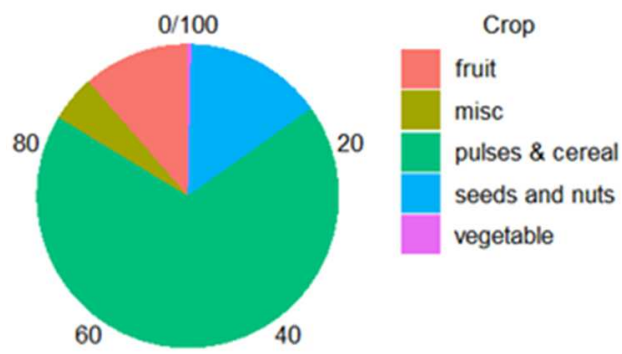

Dadra and Nagar Haveli 


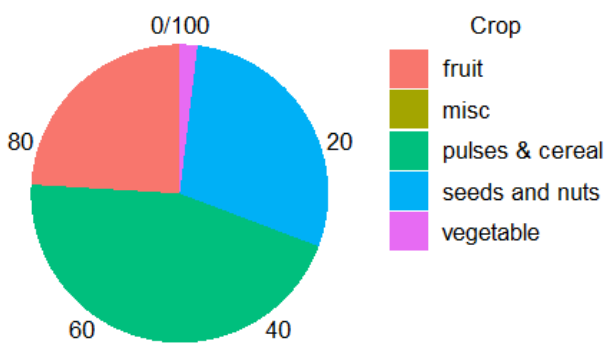

Goa

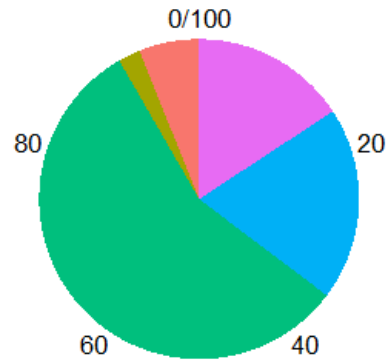

Haryana

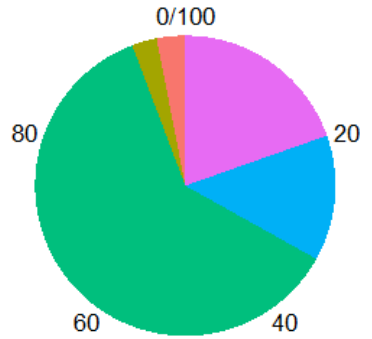

Crop

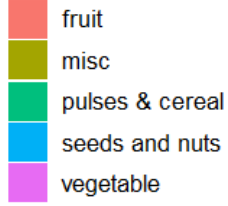

Jammu and Kashmir

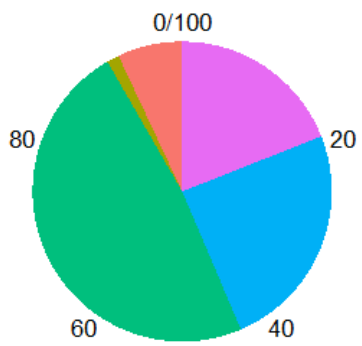

Karnataka

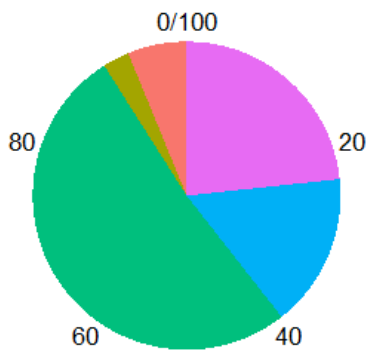

Madhya Pradesh

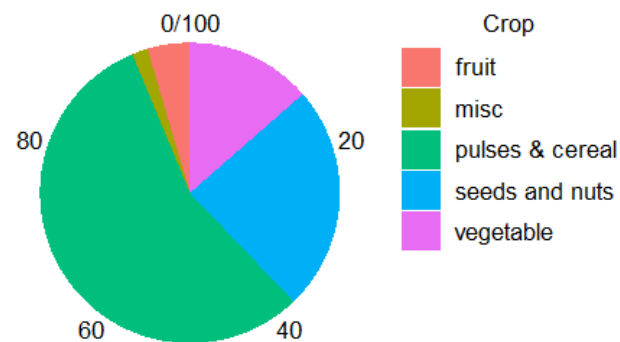

Gujarat

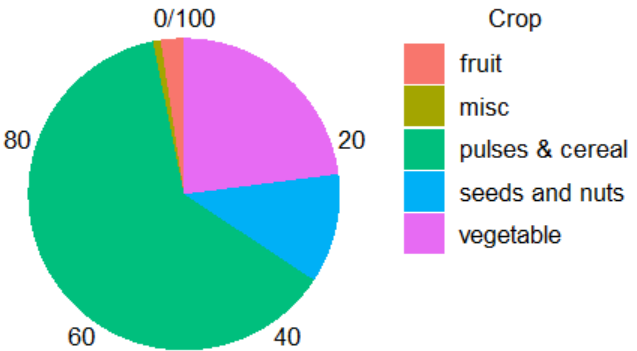

Himachal Pradesh

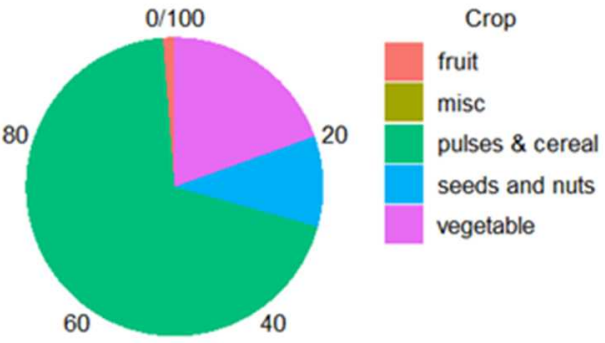

Jharkhand

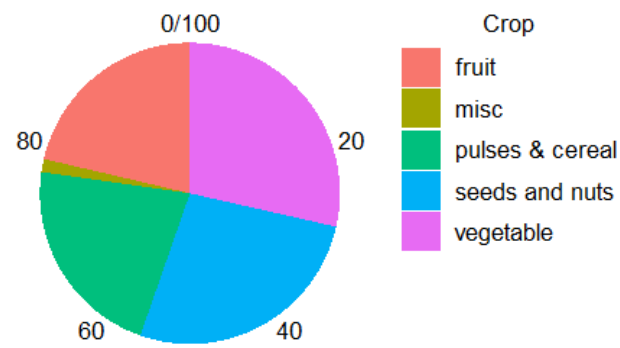

Kerala

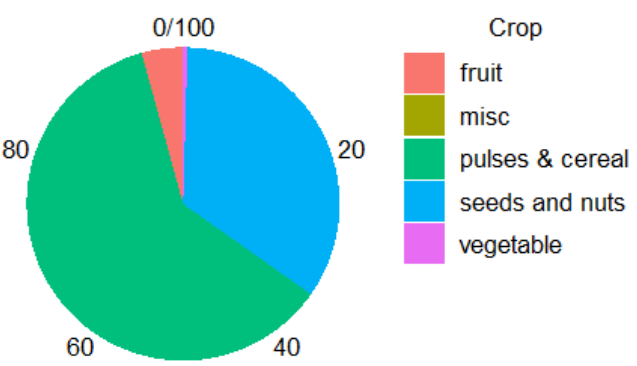

Maharashtra 


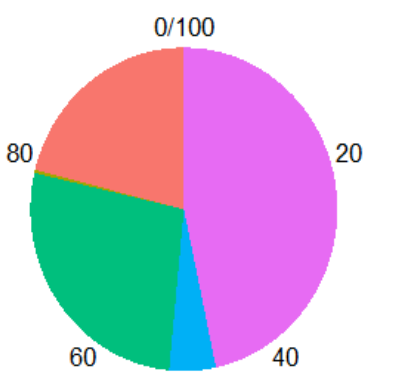

Crop

fruit

misc

pulses \& cereal

seeds and nuts

vegetable

Manipur

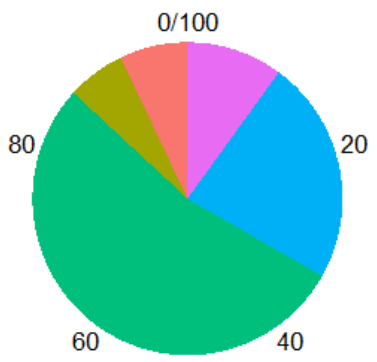

Crop

fruit

misc

pulses \& cereal

seeds and nuts

vegetable

Mizoram

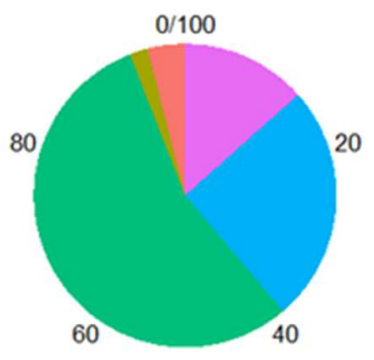

Odisha

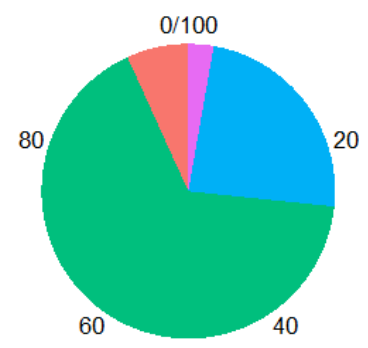

Punjab

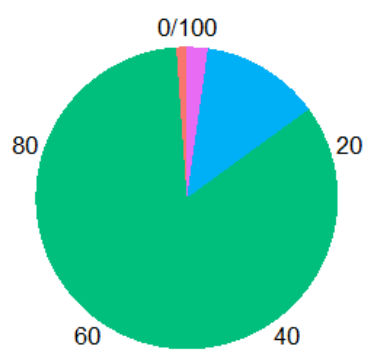

Sikkim

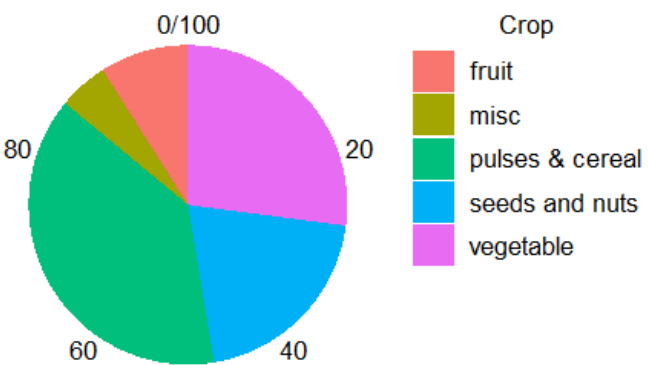

Meghalaya

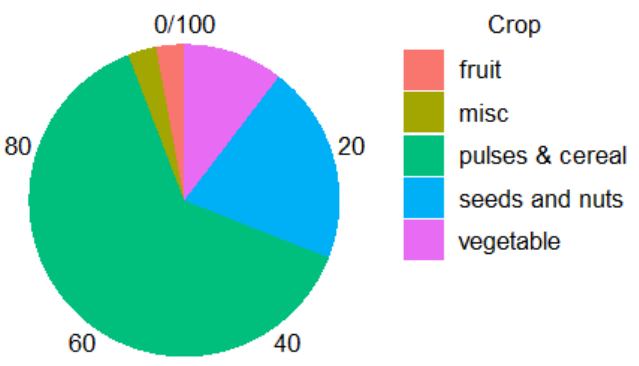

Nagaland

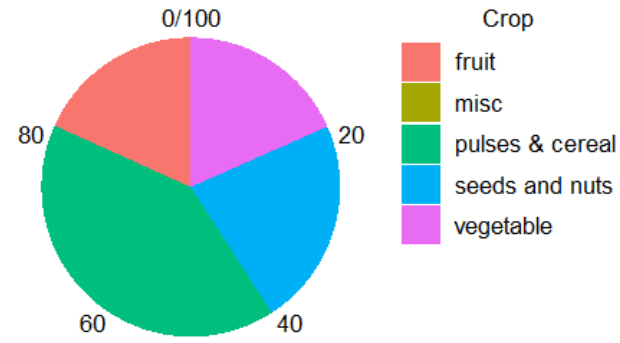

Puducherry

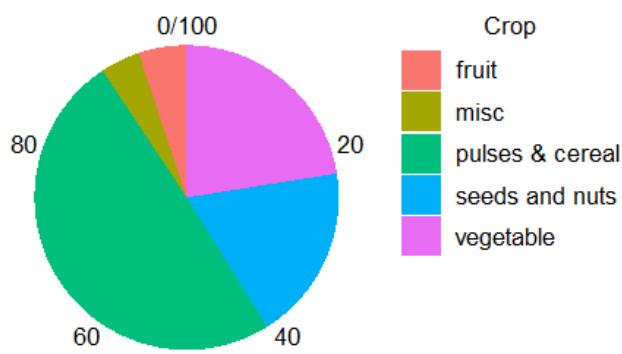

Rajasthan

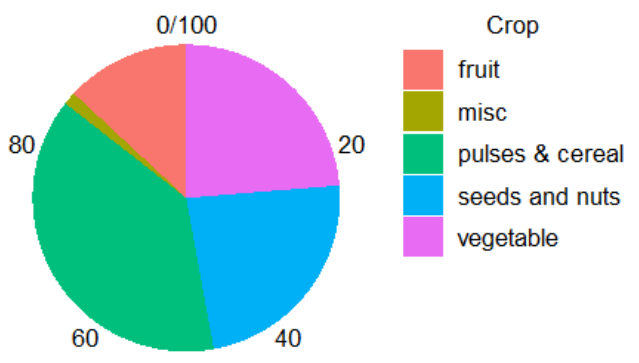

Tamil Nadu 


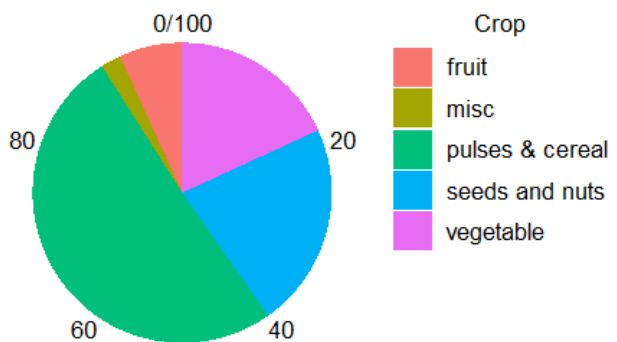

Telangana

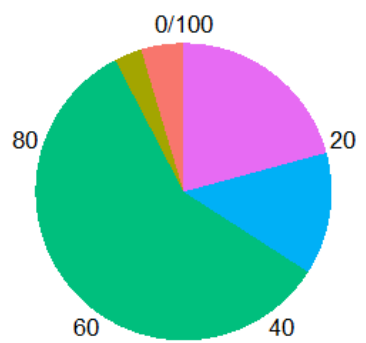

Uttar Pradesh

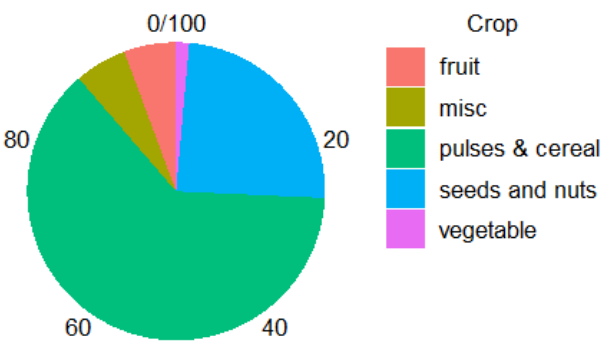

Tripura

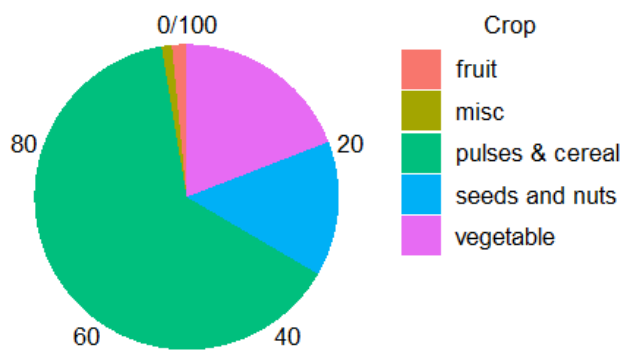

Uttarakhand

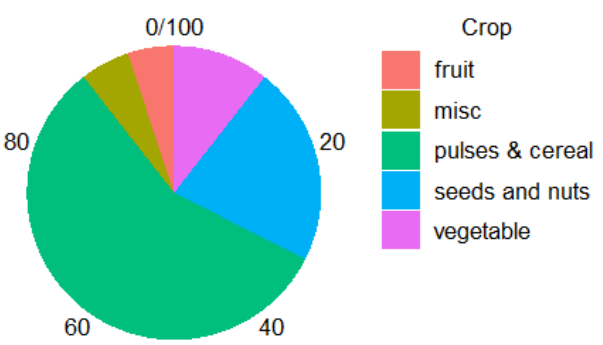

West Bengal

Fig. 5 State wise crop produce into categories of pulses, fruits, vegetables, seeds and nuts and miscellaneous

TABLE V

CATEgORIZED CROP PRODUCTION

\begin{tabular}{|c|c|c|c|c|c|}
\hline \multirow[t]{2}{*}{ Parameter } & \multicolumn{5}{|c|}{ Production } \\
\hline & fruit & $\begin{array}{l}\text { pulses } \\
\text { and } \\
\text { cereal }\end{array}$ & $\begin{array}{c}\text { seeds } \\
\text { and nuts }\end{array}$ & vegetable & miscellaneous \\
\hline Valid & 15938 & 129640 & 46597 & 43847 & 6339 \\
\hline Missing & 211 & 1798 & 956 & 447 & 318 \\
\hline Mean & $8.51 \mathrm{e}+6$ & 30794 & 13282 & 15556 & 30581 \\
\hline $\begin{array}{l}\text { Std. } \\
\text { Deviation }\end{array}$ & $6.60 \mathrm{e}+7$ & 104528 & 83356 & 93145 & 171080 \\
\hline Minimum & 0.000 & 0.000 & 0.000 & 0.000 & 0.000 \\
\hline Maximum & $1.251 \mathrm{e}+9$ & $3.63 e+6$ & $7.55 e+6$ & $3.53 \mathrm{e}+6$ & $2.59 \mathrm{e}+6$ \\
\hline
\end{tabular}

Table V shows the descriptive analysis of categorized crop production. The analysis by [4] was for each of the crop viz rice, wheat, pulses, cotton, groundnut, sugarcane, seeds etc. The area wise and yield wise calculations were done. In this paper, the pulses and cereal are the largest producers followed by seeds and nuts, fresh vegetables, fruits, and miscellaneous. 129640 tons of pulses and cereal is produced followed by 46597 tons of seeds and nuts. The horticulture production of vegetables is 43847 tons, and the fruit is 15938 tons. Miscellaneous production is the lowest with 6339 tons. The crop production from 1997 to 2014 is shown in Fig 6. In the years 2003 and 2010 there was a rise in production. The data analysis based on the crop production depending on weather helps understand the trend of the crop.

\section{Crop production}

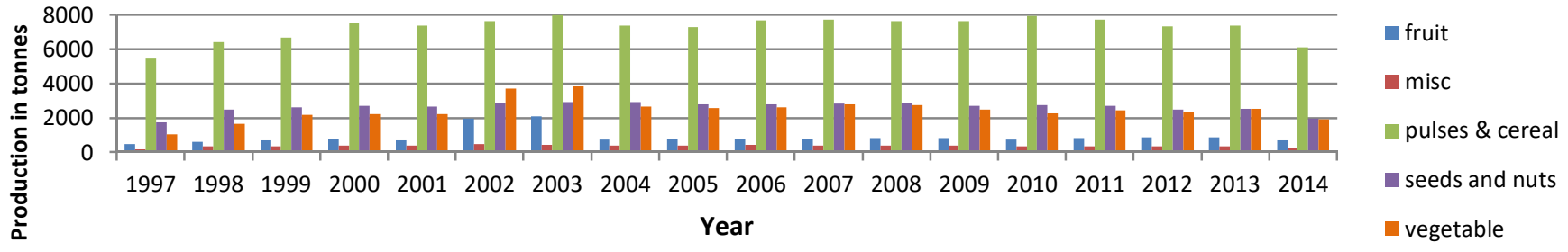

Fig. 6 Crop produce yearly 


\section{CONCLUSION}

The data analysis helps to understand crop production patterns in India by season and region. The study covers crop production in Indian states from 1997 to 2014. Climate has a huge effect on crop production. The Kharif and Rabi seasons have more products than the other seasons. During the Kharif season, the largest portion of the agricultural plot is involved, yielding the most produce compared to the other seasons. In the Kharif season, 95951 hectares of land were cultivated, yielding 94283 tons of crop production. The Rabi season has 66987 hectares of cultivable land, producing 66160 tons of crops. During the Kharif and Rabi seasons, a wider range of crops are grown. Among all Indian states, Uttar Pradesh has the highest crop production, followed by Madhya Pradesh, Karnataka, Bihar, and Assam. Pulses and cereals are the most popular products that can help meet the increasing population's nutritional needs. In the future, the most recent year's data will be used to conduct research that will aid a farmer's decision-making.

\section{REFERENCES}

[1] E. Han, A. V. M. Ines, and W. E. Baethgen, "Climate-AgricultureModeling and Decision Tool (CAMDT): A software framework for climate risk management in agriculture," Environ. Model. Softw., vol. 95, pp. 102-114, 2017, doi: 10.1016/j.envsoft.2017.06.024.

[2] A. Tesfaye, J. Hansen, G. T. Kassie, M. Radeny, and D. Solomon, "Estimating the economic value of climate services for strengthening resilience of smallholder farmers to climate risks in Ethiopia: A choice experiment approach," Ecol. Econ., vol. 162, no. November 2018, pp 157-168, 2019, doi: 10.1016/j.ecolecon.2019.04.019.

[3] A. Honecker et al., "Plant, space and time - Linked together in an integrative and scalable data management system for phenomic approaches in agronomic field trials," Plant Methods, vol. 16, no. 1, pp. 1-13, 2020, doi: 10.1186/s13007-020-00596-3.

[4] R. Guntukula, "Assessing the impact of climate change on Indian agriculture: Evidence from major crop yields," J. Public Aff., vol. 20, no. 1, pp. 1-7, 2020, doi: 10.1002/pa.2040.

[5] F. Ramírez and J. Kallarackal, "The phenology and potential ecological associations of Magenta Lilly Pilly (Syzygium paniculatum Gaertn) a native vulnerable Australian tree growing in Bogotá, Colombia," Arboric. J., vol. 41, no. 4, pp. 191-211, 2019, doi: 10.1080/03071375.2019.1642047.

[6] N. Budiharti and I. N. G. Wardana, "Utilization of plantation land for increasing Indonesian soybean production," IOP Conf. Ser. Earth Environ. Sci., vol. 472, no. 1, pp. 0-8, 2020, doi: 10.1088/17551315/472/1/012037.

[7] D. Pauli et al., "The quest for understanding phenotypic variation via integrated approaches in the field environment," Plant Physiol., vol. 172, no. 2, pp. 622-634, 2016, doi: 10.1104/pp.16.00592.
[8] S. Faghih, Z. Zamani, R. Fatahi, and M. Omidi, "Influence of kaolin application on most important fruit and leaf characteristics of two apple cultivars under sustained deficit irrigation," Biol. Res., vol. 54, no. 1, pp. 1-15, 2021, doi: 10.1186/s40659-020-00325-z.

[9] K. Balyan, S. Kumar, V. P. Chahal, and S. Kumar, "Dynamics of Indian fresh mango export," Indian J. Agric. Sci., vol. 85, no. 11, pp. 1466-1471, 2015

[10] R. Singh, M. K. Singh, A. K. Singh, C. Singh, and K. Singh, "Pulses production in India: Issues and elucidations," Pharma Innov. J., vol. 7 , no. 1, pp. 10-13, 2018, [Online]. Available: http://www.iipr.res.in/pe/introduction.asp.

[11] P. V. Kumar et al., "Algorithms for Weather Based Management Decisions in Major Rainfed Crops of India: Validation Using Data from Multi-location Field Experiments," Agron. J., 2020, doi: 10.1002/its2.20518.This.

[12] P. S. Birthal, P. K. Joshi, S. Chauhan, and H. Singh, "Can horticulture revitalise agricultural growth?," Indian J. Agric. Econ., vol. 63, no. 3, pp. 310-321, 2008.

[13] S. Datta, "Impact of Climate Change in Indian Horticulture - a Review," Int. J. Sci. Environ. Technol., vol. 2, no. 4, pp. 661-671, 2013.

[14] C. Juhász, B. Gálya, E. Kovács, A. Nagy, J. Tamás, and L. Huzsvai, "Seasonal predictability of weather and crop yield in regions of Central European continental climate," Comput. Electron. Agric., vol. 173, no. June 2019, p. 105400, 2020, doi: 10.1016/j.compag.2020.105400.

[15] S. Khaki and L. Wang, "Crop yield prediction using deep neural networks," Front. Plant Sci., vol. 10, no. May, pp. 1-10, 2019, doi: 10.3389/fpls.2019.00621.

[16] Divyosmi Goswami, "crop production dataset," 2020. https://www.kaggle.com/divyosmi2009/crop-production-in-indiastatevise.

[17] M. M. Nageswararao, B. S. Dhekale, and U. C. Mohanty, "Impact of climate variability on various Rabi crops over Northwest India," Theor. Appl. Climatol., vol. 131, no. 1-2, pp. 503-521, 2018, doi: 10.1007/s00704-016-1991-7.

[18] S. K. Malhotra, "Horticultural crops and climate change: A review," Indian J. Agric. Sci., vol. 87, no. 1, pp. 12-22, 2017.

[19] A. K. Singh and P. Sharma, "Measuring the productivity of food-grain crops in different climate change scenarios in India: An evidence from time series investigation," vol. 4, no. 16, 2018, [Online]. Available: www.discoveryjournals.org.

[20] K. F. Davis, A. Chhatre, N. D. Rao, D. Singh, and R. Defries, "Sensitivity of grain yields to historical climate variability in India," Environ. Res. Lett., vol. 14, no. 6, 2019, doi: 10.1088/17489326/ab22db.

[21] S. M. Kelkar, A. Kulkarni, and K. K. Rao, "Impact of climate variability and change on crop production in Maharashtra, India," Curr. Sci., vol. 118 , no. 8, pp. 1235-1245, 2020, doi: $10.18520 / \mathrm{cs} / \mathrm{v} 118 / \mathrm{i} 8 / 1235-1245$

[22] T. Sharma, H. Vittal, S. Karmakar, and S. Ghosh, "Increasing agricultural risk to hydro-climatic extremes in India," Environ. Res. Lett., vol. 15, no. 3, 2020, doi: 10.1088/1748-9326/ab63e1.

[23] M. Chozin, S. Sudjatmiko, Z. Muktamar, N. Setyowati, and F. Fahrurrozi, "Performances and genetic parameters estimation of yield and yield related traits in sweet corn inbred lines selected for better adaptation to organic cropping system," Int. J. Adv. Sci. Eng. Inf. Technol., vol. 10, no. 3, pp. 1252-1257, 2020, doi: 10.18517/ijaseit.10.3.2558. 